\title{
The Poems of Ghattas Maqdisi Elyas and the Remembrance of Turabdin
}

\author{
Tijmen C. Baarda ${ }^{1}$
}

Post-refereed pre-print version.

Appeared in Sayfo 1915: An Anthology of Essays on the Genocide of Assyrians/Arameans during the First World War, edited by Shabo Talay and Soner Ö. Barthoma (Piscataway: Gorgias Press, 2018).

https://www.gorgiaspress.com/sayfo-1915

Ghattas Maqdisi Elyas (1911-2008) is one of the best-known poets of the Arameans/Assyrians, who left us poetry in Classical Syriac from his youth years as well as from his old age. A victim of the Sayfo, Ghattas, or Malfōnō Denḥ̄ō as he was also known, was highly influenced by the genocide. But while he actively engages in his work with the memory of his region of birth as it was before the Sayfo, the genocide itself is almost absent in his work.

Tur Abdin, the area where Ghattas came from, is considered the heartland of the Syriac Orthodox church. Part of the Ottoman Empire, it was a heterogeneous area populated by Arameans/Assyrians, Armenians, Turks, Kurds, and Arabs. While the area never became entirely homogeneous — besides Kurdish, the area still features speakers of Arabic, Turkish and Aramaic - the events of the Sayfo during the First World War and the marginalization of non-Muslims in Turkey after the establishment of the Republic, continuing until the 1990s, made that there are very few Christians left in Tur Abdin today.

In Ghattas' early work, the memory of Tur Abdin from before the First World War plays a very important role. Many poems explicitly refer to phenomena in Ghattas' region of origin, such as the landscape, cities, churches, schools, and persons. In many poems, these landmarks are presented as something from the past —as monuments that have become inaccessible for

\footnotetext{
1 I would like to thank Professor Heleen Murre-van den Berg, Dr Dirk Bakker and Dr Andrew N. Palmer for their valuable help and comments during the various stages this paper went through. I would also like to thank Father Sait of the Mor Ephrem monastery (Glane, The Netherlands) for providing me with material published by the monastery's Bar Hebraeus Verlag.
} 
many, but kept their significance. The memories are given in an autobiographical way: usually in the first person the narrator describes his past, corresponding to the author's life.

Another important theme in Ghattas' poems is the nation. Ghattas is known to have been in favour of an Aramean identity, and the belonging of his people to a nation (umthō) is indeed a recurring feature in Ghattas' work.

Finally, many poems are not simply an eulogy to this nation of Suryōye, but also demand its elevation in the future. The fate of the Suryoye is compared to that of other nations, and its members are urged to prevent it from falling behind. Related to this is the stress on the nation's youth having a particular role in making it stronger. These three themes - nostalgia, the nation and its future - are central to this article.

Tur Abdin, as said, is one of the most important points of reference for Ghattas. That he wrote about the area as a point of nostalgia is understandable, as the poems seem autobiographical and after the Sayfo Ghattas has never returned to Tur Abdin. But remarkably, the Sayfo is not explicitly referred to in his poems. In this article, I will argue that even though an explicit treatment of the Sayfo is absent, Ghattas indirectly engages with it through nostalgia of the life it destroyed, and gives it a function in his understanding of the nation of Suryoyye.

Ghattas was not the only Aramean/Assyrian poet at the time who wrote in Syriac about themes covering the context of Sayfo. $\mathrm{Na}^{\mathrm{cc}} \overline{\mathrm{u} m} \mathrm{~F} \overline{\mathrm{a}}^{\mathrm{\rho}} \mathrm{iq}$ (1868-1930), who was one generation above Ghattas, wrote already in 1916 a poem with clear references to the genocide, even using the word sayfō. ${ }^{2}$

After an introduction to the poet, I will start with an analysis of the poem that is most relevant to this subject, his 1934 poem 'Tur Abdin'. Then I will explore, though his other poems and other information that we have about Ghattas, his understanding of the nation, and his ideas about the future of the Suryoye and the region.

2 Robert Isaf, 'Arising, or Awaking: Aramaic Language Poetry at the Turn of the $20^{\text {th }}$ Century' (paper presented at Leiden University conference 'Arabic and Its Alternatives', 15-17 June 2016). 


\section{Ghattas and the revival of Classical Syriac}

While Ghattas Maqdisi Elyas (Arabic: غطاس مقدسي إلياس Ghattās Maqdisī Ilyās) ${ }^{3}$ is generally considered one of the greatest poets of the Arameans/Assyrians, there is relatively little academic work about him. The best place to start at the moment is a long article by Assad Sauma that was published in 2011 in Parole de l'Orient. ${ }^{4}$ This article, written by a personal acquaintance of Ghattas, is especially valuable for its biographical information, the links the author gives to other modern poets of Classical Syriac, and the large amount of translations from Ghattas' work. ${ }^{5}$

Ghattas was born in the city of Midyat in 1911 in the heart of the Tur Abdin region, which was part of the Ottoman Empire, and which is nowadays in South-eastern Turkey, close to the border with Syria and Iraq. He was born on the eve of the First World War, which broke out when he was just three years old, and which would so severely hit the region. In 1915 the city of Midyat was attacked, and Ghattas fled together with many inhabitants of this city to the village of Ainwardo (today known as Gülgöze). Just after the First World War, at the age of seven, he fled from this village with his family to the city of Adana. There he found refuge in the region of Cilicia, which had come under French control from December 1918 according to the Treaty of Sèvres, which formally ended the Ottoman Empire's involvement in the war. When it became clear that the harsh peace conditions of Sèvres could not be enforced because of fierce resistance from Turkish political groups, France decided to leave the area so that it became part of the Republic of Turkey, which forced Ghattas and his family to flee once again. He went to Damascus, and except for a short stay in Beirut, he remained there until 1980. In that year Ghattas emigrated to Brazil, where he died in 2008.

Ghattas was active as an author during two periods in his life. He wrote his first set of poems in the period from 1928 to 1944 (between the age of 17 and 33). He was employed as a

3 Ghattas Maqdisi Elyas is the poet's name as it appears on the cover of his volume Tawgōne, in Latin and in Syriac script. The Syriac version of this name, however, reveals that it is actually a rendering of an Arabic name, given the use of Syriac characters with diacritics that are exclusive for Garshuni. More often however, he is referred to under the Syriac name Denḥ ō ('the rising'), usually preceded by the word malfōnō ('teacher').

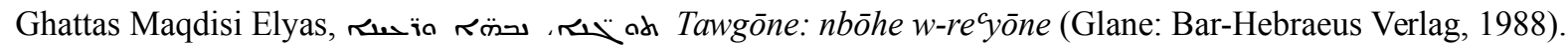
4 Assad Sauma, 'Denho Makdisi-Elyas (1911-2008): The Last Giant of the Aramean Poets', Parole de l'Orient 36 (2011): 329-66.

5 Assad Sauma was also the editor of a magazine called $A R A M$, in which Ghattas published a number of his poems. 
customs officer from 1933 until 1962, the year of his retirement. ${ }^{6}$ He started writing again after his emigration to Brazil. The long period in which he was inactive as a writer is related to his work for the government. While he kept writing in the beginning years of his employment, he stopped completely after 1947. The fact that Ghattas was not able to make his living of writing or similar services to his community was difficult for him, as he gives as an explanation for the period in which he did not write 'the official work that I was submitted to for forty years' ${ }^{7}$

Ghattas is also known as one of the forerunners in the revival or renaissance of the Classical Syriac language that characterized the nineteenth and especially the twentieth century. All his work is written in Classical Syriac, apart from some short pieces in other languages such as Arabic and Turoyo. This revival of Classical Syriac was taken on by a number of authors who reinvented the use of the language for non-religious purposes, both in the Middle East and in the diaspora. While Syriac has never stopped from being used in church, the language was less and less used for original work after the thirteenth century. In the nineteenth and twentieth centuries, however, scholars have described a revival of the classical language for writing all kind of 'modern' texts. ${ }^{8}$ Ghattas was one of the actors in this movement. Not only did he write almost everything in Syriac and not in other languages, he was also explicit about the value of the language in some of his writings and even in his poetry itself. In the introduction to his volume of poems Tawgōne (see more below), he explicitly mentions the revival of the Syriac language. ${ }^{9}$ Ghattas thus stands in a tradition of modern poetry in the Syriac language. This can also be said of the fact that he wrote about themes covering the context of Sayfo. $\mathrm{Na}^{\mathrm{cc}} \mathrm{u} m \mathrm{Fa}^{\mathrm{o}} \mathrm{iq}$ (1868-1930), who was one generation above Ghattas, wrote already in 1916 a poem with clear references to the genocide, even using the word sayfō ${ }^{10}$

6 According to Assad Sauma, he had a good position and eventually obtained a senior position. Sauma, 'Denho Makdisi-Elyas': 334.

$7 \mathrm{He}$ writes this in the introduction to Tawgōne. Ghattas Maqdisi Elyas, re्wah Tawgōne, 4.

8 S.P. Brock, 'Some Observations of the Use of Classical Syriac in the Late Twentieth Century', Journal of Semitic Studies 34 (1989): 363-75. Another key publication about the revival of Classical Syriac is Heleen Murre-van den Berg, 'Classical Syriac and the Syriac Churches: A Twentieth-Century History', in Syriac Encounters: Papers from the Sixth North American Syriac Symposium, Duke University, 26-29 June 2011, edited by M. Doerfler, E. Fiano and K. Smith (Peeters: Louvain, 2015), 119-48.

9 He uses the phrase nuhōme d-hōnō leshōnō 'the resurrection of this language', i.e. Syriac. Ghattas Maqdisi Elyas, Tawgōne, 2.

10 Robert Isaf, 'Arising, or Awaking: Aramaic Language Poetry at the Turn of the $20^{\text {th }}$ Century' (paper presented at Leiden University conference ‘Arabic and Its Alternatives’, 15-17 June 2016). 
Anecdotic information suggests a considerable legacy of Ghattas' poems in popular culture. For instance, Assad Sauma reports in his article about Ghattas that a poem he wrote in 1931 about the monastery of Qenneshrin (Syria) was later adopted as a song, which 'became very popular and was sung by the Syriac students in West Syriac schools. ${ }^{11}$ However, a systematic study of the way Ghattas' poems have been read and used by others has yet to be written. A more in-depth study of Ghattas' legacy could moreover not only provide a better understanding of twentieth-century poetry among the Arameans/Assyrians, but also fill in gaps of our knowledge of the revival of the Classical Syriac language in the nineteenth and twentieth centuries.

\section{The poem 'Tur Abdin': the territorial basis}

One of Ghattas' best-known poems is 'Tur Abdin' (Tur 'Abdin), written in 1934, in the author's early twenties, hence in the first period in which he was active as a poet. To my knowledge it was not published until 1988, when it appeared in Tawgōne, one of the five volumes of poems of which it can be said that they together form Ghattas' oeuvre. ${ }^{12}$ Contrary to the other four volumes, Tawgōne includes many poems from Ghattas' early period. Except from its appearance in Tawgōne it was earlier included in Qōlo Suryōyō, the journal of the archdiocese of The Netherlands published by its former bishop, Mor Julius Yeshu Çiçek. Part of the poem appeared a couple of times on the Internet in an English translation. With its 13 stanzas it is the longest in Tawgōne.

As the name of the poem suggests, 'Tur Abdin' is about the region where Ghattas was born. It is partly written from a first-person perspective, and the extent to which events described in the poem correspond to Ghattas' life suggests that it can be considered autobiographic. The poem can be roughly divided into four parts on the basis of its contents. To give an impression of the poem, as well as to point out a number of issues to discuss, I will cite from all of the four parts. The first section (stanzas 1 through 5) forms a description of Tur Abdin:

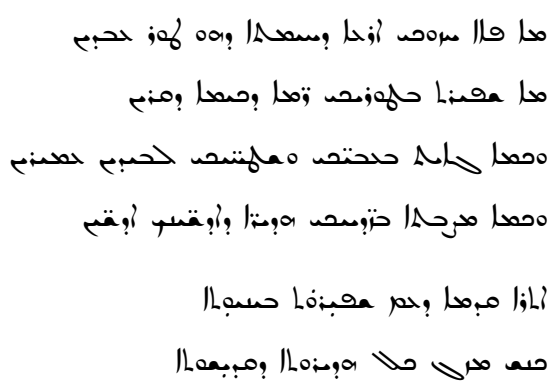

11 Sauma, 'Denho Makdisi-Elyas', 352.

12 Ghattas Maqdisi Elyas, Tawgōne, 42-4. I used this edition of 'Tur Abdin' and other poems in this article. 


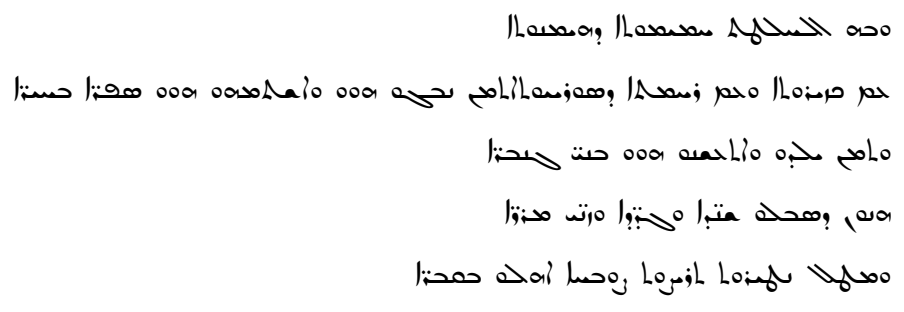

(Stanza 1) Your appearance is so beautiful, beloved land of Tur Abdin you are so beautiful with your high mountains, extending above the stars I used to enjoy your forests; your open fields were full of wood and grass you are so well-formed with your attractive rivers of all kinds ${ }^{13}$

Two more stanzas describe the nature of Tur Abdin, one stanza praises the religious life and the fifth stanza is about Midyat, the city in the 'middle of the mountain', 'keeping an eye on the valleys as a queen'.

The second section (stanzas 6 through 8) are about the people of Tur Abdin, hailing especially the region's writers for their cultural endeavours. I will quote it in full, as it contains many elements that I will discuss in this paper:

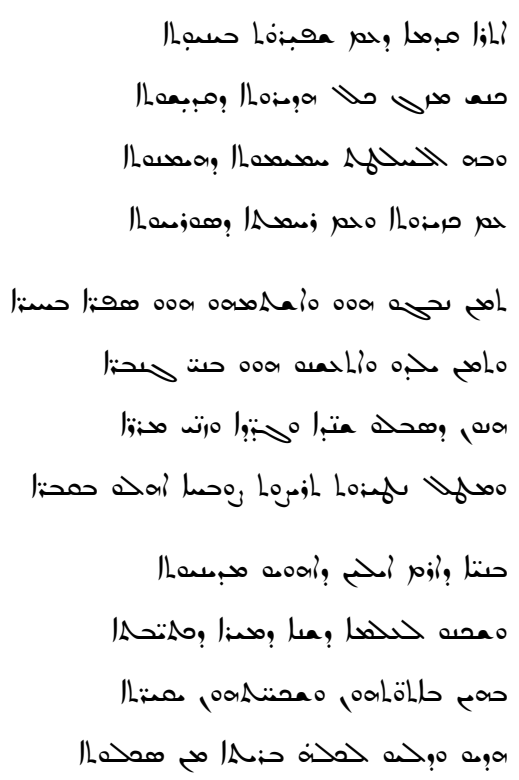

(Stanza 6) Ancient land, which with beautiful nature brought together and united all honour of holiness

Where the zeal of faith was mixed with bravery and love for Suryōyuthō

13 Ibid., 42. The translations are mine unless otherwise stated. 
(Stanza 7) There the glorious writers rose and became famous and it is there that mighty people were born and hardened Those who suffered torments and bitter sorrows, and all kinds of bitterness and because they kept their orthodoxy, the graves were derided

(Stanza 8) The children of Aram, those who created civilization and who gave the world the beautiful gift of writing With that, with their valuable glyphs and inventions they guided and raised all of the Creation from ignorance ${ }^{14}$

Two issues need to be discussed here. First, Ghattas gives here details about his ideas of the Suryōye to belong to a nation. While the word that Ghattas uses elsewhere for 'nation', umthō, is not used in this poem, this part is praising the people from Tur Abdin. In the sixth stanza, the narrator tells that the land of Tur Abdin is not only a place of 'the honour of holiness' with the 'zeal of faith', but that it is mixed with 'love for the Suryōyo culture' (Suryōyuthō, see below for a discussion of this word). In the seventh stanza, except for highlighting the suffering of the people of Tur Abdin, it also praises their merits: among them there were 'glorious writers', and, significantly, they 'kept their orthodoxy', not submitting to any other faith. Stanza 8, then, describes these people as the 'children of Aram' (bnayō d-Ōōom), or Arameans, and interestingly, as creators of civilization. In the next section, I will go deeper into Ghattas' understanding of the nation. Second, while Ghattas confirmed in an interview that he never wrote about the Sayfo, in the seventh stanza he comes fairly close: the suffering and derision of graves is likely to refer to the genocide.

In the third part (stanzas 9 to 11) Ghattas becomes more explicit about these events. In this part he address the reader in the second person, urging compatriots who consider emigrating from Tur Abdin to think twice. The one who visits Midyat gets a special task:

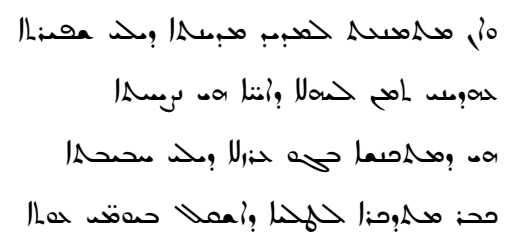

(Stanza 10) If you arrive in Midyat, my beautiful city

Bring me back to memory with that glorious group of brothers

14 Ibid., 43. 
Who are gathered in my beloved hut

Maybe they remember the child who left during the days of need ${ }^{15}$

In other words, the narrator urges the reader to bring him into remembrance. What is meant by the 'glorious group of brothers' in the narrator's 'beloved hut' is not entirely clear, but the last line is very significant. It corresponds to what we know from Ghattas' biography: at the age of three he had to flee from Midyat to Ain Wardo. It is highly likely that this passage ought to be understood autobiographical and that this passage therefore refers to the events of the Sayfo.

The last part (stanzas 12 and 13) concludes the poem and goes back to a general praise of Tur Abdin. In the last stanza the pain of the mountain is described:

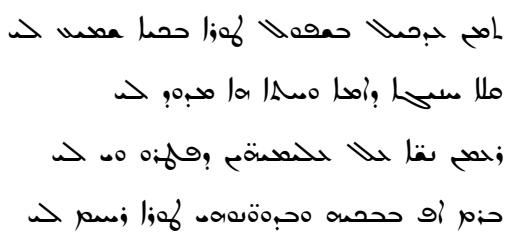

(Stanza 13) There, at the foot of the mountain, I still hear lamentation

a sad voice of a mother and a sister - lo! it bothers me

The women are sorry for the youngsters who left, woe is me!

but even with its mourning and misery I love the mountain ${ }^{16}$

The poem only contains indirect references to the Sayfo: the event that is referred to in the first instance is mentioned in strong terms ('the graves were derided'), but it is not made explicit what exactly is meant by it, and there is even a possibility that it refers to an event that did not happen during the First World War. The second instance is less ambiguous, but refers only to the narrator's fleeing from Midyat and does not make explicit the reasons why this was necessary. Nevertheless, both pieces are enough to show that in this poem, which is about the old heartland of the Syriac Orthodox, the Sayfo is not completely absent.

\section{The nation of Suryōye and its elevation}

As is well known, the features of the nation the Arameans/Assyrians belong to are controversial, all actors have their own positions in the debate. Ghattas was outspoken about

15 Ibid., 44.

16 Ibid. 
his position in this debate, as is apparent from interviews, but also in his poems reveal details about his opinions. In this section, I will argue that a major function of Ghattas' poems was to help reinforce a certain kind of community feeling. This community, that Ghattas often refers to as a 'nation' (umthō) of Suryōye, has Tur Abdin as its homeland.

Despite the fact that Ghattas received part of his education at the orphanage in Adana, which was known as an Assyrian school, Ghattas explicitly rejected Assyrianism. This is evident from an interview that was held by Zakay Joseph and that appeared in Ghattas' last volume of poems, Fire Lqishōye, and which was also published on the Aramean website www.urhoy.info. ${ }^{17}$ In this interview, Ghattas is asked for reasons why he did not support the Assyrian movement, and in particular why he did not follow his friend Abrohom Gabriel Sawme (1913-1996), who was a fellow student in Adana and who became active in Assyrianism. According to Ghattas, the Assyrian movement did 'not rely on solid historic and cultural basis', saying that he did not discuss political matters with Abrohom Sawme, but only language and culture. ${ }^{18}$

In this interview, the words 'Aramean culture' and 'Aramean people' are used numerous times, both in the question of the interviewer and in Ghattas' answers. In this sense, he should be considered a supporter of Arameanism. Can Ghattas' Aramean identity be traced back to the poems from his early period of writing (1928-1944)? For that, the references to Arameans are relatively rare: the poem 'Tur Abdin' is an exception. The rest of his poems and other works in Syriac contain dozens of instances of the words Suryōyō, ${ }^{19}$ its plural Suryoye and

17 This website, which was in favor of an Aramean identity, is no longer available, but its historical pages including the interview can be found on the Internet Archive: Zakay Joseph, 'Interview with Denho Ghattas Makdisi Elias', https://web.archive.org/web/20091029161441/http://www.urhoy.info/interview-ghattas.html (no date). The interview was later republished on the website of the Aramean Democratic Organization, and can at the time of writing be found here: http://www.aramaicdem.org/English/History/Inte_view_with_Denho_Ghattas_Makdisi_Elias.htm, last seen 30 March 2016. 18 Ibid.

19 I do not translate the word Suryōyō and the words related to it to English with 'Syriac', 'Syriacs' and 'Syriac culture', except if they are obviously used in the context of the Syriac language. I keep the option open that for Ghattas the Syriac word did not have the same connotations as their usual English-language counterparts.

Indeed, the word Suryōyō is considerably often not translated as Syriac, but differently. Naures Atto mentions an interesting case where somebody, who self-identifies as Assyrian, translates both the words Suryōye and Ōthurōye as 'Assyrier' in Swedish, because they consider them synonyms. At the same time, a closer analysis reveals that these words sometimes have different meanings when she uses them in Aramaic language, the first referring to the Syriac Orthodox church members and the second to people from the East Syriac churches as well. Naures Atto, Hostages in the Homeland, Orphans in the Diaspora, Orphans in the Diaspora Identity 
related words such as Suryōyuthō, which could be translated as something like 'Suryōyo culture' or 'Suryōyō-ness' ${ }^{20}$ This lack of references to the Arameans is in sharp contrast to his later work, as Assad Sauma points out. ${ }^{21}$

Ghattas' development towards an Aramean identity is not invisible in his volume Tawgōne, though. The volume contains introductory pieces to the volume in Arabic and in Syriac. The two texts, both written shortly before the publication of the volume (1988), are very different from each other, and the Arabic one is shorter than the introduction in Syriac. The Arabic text is entitled 'The Syriac language (Aramaic)', and contains three pages of handwritten, highly vocalized text in Modern Standard Arabic. It starts as a rather general introduction about the Syriac language, as it explains the similarities between Syriac and Arabic and their common origins as Semitic languages.

In the Arabic introduction, the word that the author uses for Suryōyō is, as expected, Suryāni. Like the Syriac word, this word can refer to the Syriac language, but also to a people (alSuryān) or a culture. As a reference to the language, it can safely be translated as 'Syriac', but as a reference to a people or culture this translation is not to be taken for granted, just like the Syriac counterpart of this word. In the Arabic introduction the author writes explicitly about the difference between the words Arāmī and Suryānī. Interestingly, in the Arabic introduction Ghattas suggests that Suryān̄i is a better term to refer to his people than Arāmī 'Aramaic', as he writes the following:

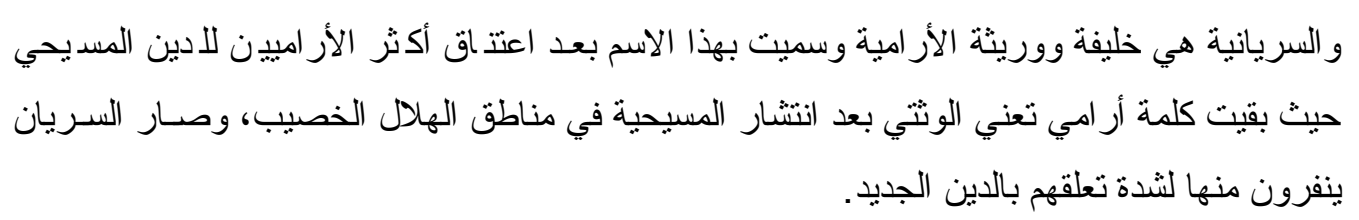

Syriac is the successor and heir of Aramaic. It became known under this name after the conversion of most of the Arameans to the Christian faith, whereas the word 'Aramaic' continued to mean 'pagan' after the spread of Christianity in

Discourses Among the Assyrian/Syriac Elites in the European Diaspora (Leiden: Leiden University Press, 2011), 438-9.

20 See for a discussion of this word Atto, Hostages in the Homeland, 370-2.

21 Sauma, 'Denho Makdisi-Elyas (1911-2008)': 329-66. 
the lands of the Fertile Crescent. The Suryāni $-\mathrm{s}^{22}$ started to avoid the name to strengthen their belonging to the new faith. ${ }^{23}$

In the lines above, Ghattas explains the difference between Arāmī and Suryānī as a shift to Suryānī because of the negative connotation the word had in relation to paganism. It is indeed a common idea that the name Suryōyō, with its Arabic counterpart Suryān̄̄, was taken since the adoption of Christianity. Naures Atto explains that people who call themselves Suryoye trace their history back to the early years of the church. ${ }^{24}$ This explanation seems to be conflicting with the positive feelings of Ghattas for the Aramaic identity as apparent in his interview and the secondary literature about him, but Ghattas gives no more information in this Arabic text that could clarify his thoughts. The Syriac introduction that directly follows goes deeper into the value of the Syriac language for the nation, but in sharp contrast to the Arabic introduction does not mention its Aramean origins. ${ }^{25}$

The word that Ghattas uses for describing the community is generally umtho, which can be translated as 'nation' and which is a cognate of the Arabic word umma. ${ }^{26}$ This should be seen in relation to the word 'amō 'people', which has also been used to refer to similar identities, but which has more been used to indicate the Suryoye as a religious group. ${ }^{27}$ Other words Ghattas uses to refer to a certain sense of Suryōyo identity are mōthō 'homeland' or 'motherland', and also athrō 'region' and $a r^{c} \bar{o}$ 'land'.

Assyrianism was explicitly rejected by Ghattas according to his interview and as confirmed by Assad Sauma. But how inclusive is Ghattas' understanding of the nation of Suryoye? Does it embrace all of Syriac Christianity or is it specifically West-Syriac? Just as there is no consensus about the name of the Assyrians/Arameans as a people, there is no universal agreement about the boundaries of the people: sometimes all (originally) Aramaic-speaking

22 Arabic: al-Suryān.

23 Ghattas Maqdisi Elyas, Tawgōnē, IV.

24 Atto, Hostages in the Homeland, 442-3.

25 Ghattas Maqdisi Elyas, Tawgōnē, 2-5.

26 The Arabic umma is well known in the sense of the Islamic umma, but is also used for worldly nations, as in al-umam al-muttahida 'United Nations'.

27 This distinction is also shown by Atto, who shows that many people in the diaspora have a double idea of an Assyrian/Syriac identity, one religious and one secular, which may come with different narratives and boundaries. The word umthō 'nation' is used in a secular sense, while the word 'amō 'people' may have both meanings. Hostages in the Homeland, 437-8. 
people are included, including even the Greek Orthodox and the Maronites, but it can also be restricted to one specific church. ${ }^{28}$ An understanding of the nation as only including the Syriac Orthodox, possibly together with the Syriac Catholic, is not uncommon and has old roots. ${ }^{29}$ It is a possibility that cannot be immediately ruled out and has to be discussed.

The inclusiveness of Ghattas' nation to embrace also the East-Syriac world is nowhere denied. However, the strong presence of Tur Abdin in his poetry, being a key region for the Syriac Orthodox, suggests that his words are especially directed towards the West-Syriac branch. The same is true for Ghattas' references to the Sayfo. Even though the Sayfo is understood as the whole of the atrocities against Arameans/Assyrians in and around 1915, the events to which Ghattas refers happened in the region of Tur Abdin and are more or less specific to the WestSyriac branch. In addition to that, there are certain other factors, such as the fact that Ghattas mainly worked through Syriac Orthodox institutions to publish his work, and that his poems were published in West-Syriac (Sertō) script, that Ghattas relates more to people with a Syriac Orthodox (or to a lesser extent Syriac Catholic) background than others. On the other hand, there are elements in Ghattas' understanding of the nation that naturally embrace the EastSyriac branch as well, such as his stress on the Aramaic language. Both an explicit denial and assertion of inclusiveness are lacking, which might have been the intention of the poet.

Another issue, which I will not go deep into here, is the role of religion in Ghattas' notion of the nation of Suryōye. Ghattas rarely includes religious themes in his poetry, nor has he talked about it in interviews. One notable exception is the line from the poem 'Tur Abdin' I discussed above, where the fact that the people of Tur Abdin 'kept their orthodoxy' was praised. Religion therefore seems to have only a minor role in Ghattas' understanding of the nation. This is in line with the general understanding of the word umtho as having a secular connotation. ${ }^{30}$

\section{Tur Abdin, Suryoye and the future of the nation}

Ghattas' poem 'Tur Abdin' establishes this region of today's South-eastern Turkey as the foundation of the Suryoye as a people. The region is explicitly praised as the place of origin of

28 Atto, Hostages in the Homeland, 433ff.

29 Bas ter Haar Romeny with Naures Atto, Jan J. van Ginkel, Mat Immerzeel and Bas Snelders, 'The Formation of a Communal Identity among West Syrian Christians: Results and Conclusions of the Leiden Project', Church History and Religious Culture 89:1-3 (2009): 1-52.

30 See for a discussion about the importance of the question if religion has a place in Aramean/Assyrian identity Sarah Bakker Kellog, 'Ritual sounds, political echoes: Vocal agency and the sensory cultures of secularism in the Dutch Syriac diaspora', American Ethnologist 42:3 (2015): 431-445. 
these people, and as a centre for its religion. The poem also acknowledges that terrible things have happened in Tur Abdin by referring discreetly to the events of the Sayfo. The poem also acknowledges that many people — of which Ghattas himself is one-have left the region. Nevertheless, for the Suryoye, the significance of the region has not diminished. Other poems give details about who these Suryoye are. We have seen that Ghattas regards them as a nation (umthō), usually called Suryōye, or al-Suryān in Arabic, and in English more often Arameans. This nation might encompass all people who belong to one of the Syriac churches, but Ghattas focuses on the Syriac Orthodox heritage.

When reading these poems together, we can assert that for Ghattas, Tur Abdin was of a great importance to the nation of Suryoye. The genocide of 1915 is central to this understanding: in a few cases by references to the atrocities themselves, and more often by making visible the Sayfo's painful consequences, especially by showing the scattering of the Suryoye around the world and their disappearance from Tur Abdin. However, what does Ghattas think about the future of this nation of Suryoye? Is there hope for the nation after the First World War, or is it something from the past? And should Tur Abdin be seen as a monument in the collective memory of the nation - as something of the past — or should the Suryoye even return to the region?

As for the future of the nation, it should be stressed that Ghattas devotes great attention to the elevation of the nation. For instance, his poem 'Youth' ('laymuthō, 1930) is an eulogy to the youth of the nation (again umthō) in a refrain (unithō) and four stanzas, ${ }^{31}$ which is seen as a promise for the future, as its refrain says: 'Peace to you, oh youth / daughter of the nation that does not die / We are carried on your arms / building of our revival.' It should be kept in mind that Ghattas was only 18 or 19 years old at the time he wrote this, and therefore belonged to the youth himself. The next generation is supposed to 'renew' the nation, and thus to preserve its antiquity: 'Renew our nation with the new generation / Preserve our antiquity with the ideas of today / The years proceed quickly / Do not destroy their opportunities.' In the last stanza the 'boys, girls, men and women' are urged to work 'hastily for the elevation', in which Ghattas explicitly uses the word $m^{c}$ alyuthō, which means 'elevation', and is an anagram of the title of the poem, 'laymutho 'youth'. ${ }^{32}$ His poem 'Compatriots' (Bnay mōthō, two stanzas, 1931), ${ }^{33}$ then, addresses the whole people, urging them as well to haste in order to bring back the honour of their ancestors, this time because other nations seem to do better, as shows the 31 Ghattas Maqdisi Elyas, Tawgōne, 30.

32 I would like to thank Dr Andrew N. Palmer, who noticed this.

33 Ghattas Maqdisi Elyas, Tawgōne, 32. 
second stanza: 'Let us observe all nations / for see, they rush forwards / Let us therefore rush / quick, quick, for the elevation.' The element of elevation of the nation shows that in Ghattas' view the nation of Suryoye is not something that has been lost, irrevocably damaged or as having no future. Instead, Ghattas has a rather optimistic view. As long as the new generation works hard to 'elevate' the nation, while preserving its traditions and presumably also its unity, there is a bright future for the Suryoye, either in the homeland or in the diaspora.

As for the regional aspect of Ghattas' understanding of the nation, with Tur Abdin as its centre, it should be noticed that there are many indications that Ghattas saw emigration outside the Middle East as something negative. Assad Sauma cites a number of poems in which Ghattas laments the fact that Ghattas spent all the years from 1980 outside the Middle East, using phrases such as 'Woe unto immigration'. ${ }^{34}$ Other poems speak about emotions such as anxiety and longing, to an extent that Sauma describes Ghattas' life in Brazil as 'unhappy'. ${ }^{35}$ There is also reason to believe that Ghattas felt guilty for emigrating to Latin America. In the Arabic introduction to Tawgone cited above, Ghattas expresses the hope that he could 'pay back a small part of the great debt which was laying on my shoulders for many years ${ }^{36}$ While this can be interpreted as guilt for not having written poetry for a long time, during his employment as a customs officer, it may also refer to his emigration to Brazil. ${ }^{37}$ By writing poetry, he found himself able to pay back part of his debt (Arabic dayn) to the nation. In addition to that, we saw that in the poem 'Tur Abdin' three stanzas are devoted to urge the reader not to leave the region. For Ghattas, the original region of the Suryoye- the Middle East in general and particularly Tur Abdin-was still of concrete importance after the First World War. Nevertheless, it is acknowledged that life in Tur Abdin is not anymore as it used to be. Even Ghattas himself never visited Tur Abdin after he left. In his interview with Zakay Joseph he says the following: '[L]ater in my long life I traveled to many countries all over the world, but I was reluctant to go to Turkey. The atrocities which Turkey committed against our people, left strong feeling in my heart and mind, and prevented me from traveling there. ${ }^{38}$

\footnotetext{
34 Sauma cites a poem with the translated title 'Far away from one's own Homeland', from the volume Fire Lqishōye 38-9. 'Immigration' should probably be read as 'emigration', but I have not seen the original. Sauma, 'Denho Makdisi-Elias', 365.

35 Ibid., 348-50.

36 Ghattas Maqdisi Elyas, Tawgōne, 1.

37 As Andrew N. Palmer noted, someone may feel guilty for leaving their old life with 'poverty and piety' for a situation in which they are 'rich and free from suppression'.

38 See citation above for the URL to this interview.
} 


\section{Bibliography}

Atto, Naures. Hostages in the Homeland, Orphans in the Diaspora Identity Discourses Among the Assyrian/Syriac Elites in the European Diaspora. Leiden: Leiden University Press, 2011.

Bakker Kellog, Sarah. 'Ritual sounds, political echoes: Vocal agency and the sensory cultures of secularism in the Dutch Syriac diaspora'. American Ethnologist 42:3 (2015): 431445.

Brock, S.P. 'Some Observations of the Use of Classical Syriac in the Late Twentieth Century'. Journal of Semitic Studies 34 (1989): 363-75.

Ghattas Maqdisi Elyas, Hebraeus Verlag, 1988.

ter Haar Romeny, Bas with Naures Atto, Jan J. van Ginkel, Mat Immerzeel and Bas Snelders. 'The Formation of a Communal Identity among West Syrian Christians: Results and Conclusions of the Leiden Project'. Church History and Religious Culture 89:1-3 (2009): 1-52.

Isaf, Robert. 'Arising, or Awaking: Aramaic Language Poetry at the Turn of the $20^{\text {th }}$ Century'. Paper presented at Leiden University conference 'Arabic and Its Alternatives', 15-17 June 2016.

Murre-van den Berg, Heleen. 'Classical Syriac and the Syriac Churches: A Twentieth-Century History'. In Syriac Encounters: Papers from the Sixth North American Syriac Symposium, Duke University, 26-29 June 2011, edited by M. Doerfler, E. Fiano and K. Smith, 119-48. Peeters: Louvain, 2015.

Sauma, Assad. 'Denho Makdisi-Elyas (1911-2008): The Last Giant of the Aramean Poets'. Parole de l'Orient 36 (2011): 329-66.

Zakay, Joseph. 'Interview with Denho Ghattas Makdisi Elyas'. No date. Available at https://web.archive.org/web/20091029161441/http://www.urhoy.info/interviewghattas.html 